\title{
Nowe metody diagnostyki amyloidozy serca Seria przypadków amyloidozy transtyretynowej
}

\author{
Novel diagnostic pathways in cardiac amyloidosis \\ Case-series study on transthyretin amyloidosis
}

\author{
Paweł Rubiś ${ }^{1}$, Ewa Dziewięcka ${ }^{1}$, Katarzyna Holcman ${ }^{1}$, Wojciech Szot $^{2}$, \\ Sylwia Wiśniowska-Śmiałek ${ }^{1}$, Agata Leśniak-Sobelga ${ }^{1}$, \\ Marta Hlawaty ${ }^{1}$, Piotr Podolec ${ }^{1}$, Magdalena Kostkiewicz ${ }^{1,2}$ \\ ${ }^{1}$ Klinika Chorób Serca i Naczyń, Krakowski Szpital Specjalistyczny im. Jana Pawła II, Kraków \\ ${ }^{2}$ Zakład Medycyny Nuklearnej, Krakowski Szpital Specjalistyczny im. Jana Pawła II, Kraków
}

\begin{abstract}
Streszczenie
Amyloidozy to heterogenna grupa chorób wywotanych polimeryzacja nieprawidtowo sfatdowanych biatek, które odktadaja sie w macierzy zewnatrzkomórkowej wielu organów. Odktadanie amyloidu w przestrzeni zewnatrzkomórkowej miokardium powoduje stopniowe pogarszanie funkcji rozkurczowej, a na pózniejszych etapach także funkcji skurczowej, co prowadzi do rozwoju fenotypu kardiomiopatii restrykcyjnej. Znanych jest co najmniej 36 biatek, które moga tworzyć ztogi amyloidu. Jedna z czestszych sercowych postaci amyloidozy jest amyloidoza transtyretynowa (ATTR), nabyta lub dziedziczna wywotana mutacja w genie transtyretyny. Amyloidoza transtyretynowa jest gtównie postrzegana jako choroba neurologiczna, jednak spektrum narzqdów dotkniętych choroba, a tym samym możliwych zaburzeń, jest bardzo zróznicowane, co utrudnia jej diagnostyke. Natomiast, ze wzgledu na wprowadzenie nowego leku - tafamidisu, wczesne rozpoznanie choroby staje sie kluczowe dla leczenia chorych na ATTR, szczególnie z zajeciem serca. W niniejszej pracy przedstawiono serie 4 przypadków pacjentów z potwierdzona ATTR.
\end{abstract}

Słowa kluczowe: kardiomiopatia restrykcyjna; amyloidoza transtyretynowa, ATTR

Hematologia 2018; 9, 3: 254-264

\section{Abstract}

The systemic amyloidoses are diseases induced by misfolded proteins. These insoluble proteins deposit in extracellular space. Infiltration of the heart by amyloid can result in progressive diastolic and systolic dysfunction and restrictive cardiomyopathy phenotype - left ventricle hypertrophy and stiffness. More at least 36 different precursor proteins have the propensity to form amyloid fibrils. One of the most common amyloidoses infiltrating the heart is transthyretin amyloidosis (ATTR) - acquired or hereditary caused by tranthyretin gene mutations. ATTR is generally considered a mainly neurological disease, but it is phenotypically heterogeneous and the clinical spectrum of the disease varies widely, which makes the diagnosis a real challenge. However, due to introduction of a new drug against ATTR, tafamidis, early diagnosis is crucial for improvement of the prognosis. In this article we would like to present the case series of ATTR, which was diagnosed by heart scintigraphy or genetic testing.

Key words: restrictive cardiomyopathy, transthyretin amyloidosis, ATTR

Hematologia 2018; 9, 3: 254-264

Adres do korespondencji: Ewa Dziewięcka, Klinika Chorób Serca i Naczyń, Krakowski Szpital Specjalistyczny im. Jana Pawła II, ul. Prądnicka 80, 31-202 Kraków, e-mail: ewa@dziewiecka.pl 


\section{Wprowadzenie}

Amyloidozy to heterogenna grupa chorób charakteryzujących się depozycją złogów amyloidu w macierzy zewnątrzkomórkowej wielu organów, $\mathrm{w}$ tym serca [1]. Histopatologicznie amyloid jest nieprawidłowo uformowanym białkiem, którego zmiana konfiguracji przestrzennej (pofałdowanie) powoduje łączenie się w większe nierozpuszczalne kompleksy i odkładanie (wytrącanie) w tkankach. Polimeryzacja monomerów białek może być uwarunkowana na przykład mutacją w genie białka, która zaburza jego trzeciorzędową strukturę [2]. Te patologiczne białka tracą wówczas swoją fizjologiczną funkcję i tworzą hydrofobowe płytki amyloidowe wokół komórek. Patomechanizm uszkodzenia struktury i funkcji komórek w przebiegu odkładania amyloidu jest złożony. Jednym $z$ dość dobrze określonych mechanizmów (zwłaszcza w odniesieniu do amyloidozy sercowej) jest zaburzenie gospodarki wapniowej komórki, co powoduje dysfunkcję mitochondriów oraz błony komórkowej, aktywację wolnych rodników tlenu i w efekcie śmierć komórki [3, 4].

Odkładanie amyloidu w przestrzeni zewnątrzkomórkowej miokardium powoduje stopniowe pogarszanie funkcji rozkurczowej, a w bardziej zaawansowanych stadiach - także funkcji skurczowej, co prowadzi do powstania fenotypu kardiomiopatii restrykcyjnej [5, 6]. Obraz serca w kardiomiopatii restrykcyjnej charakteryzuje się pogrubieniem ścian serca (łagodnym/umiarkowanym przerostem) i jego sztywnością, co powoduje wzrost ciśnień wewnątrzsercowych i niski rzut serca [6]. Podstawą klasyfikacji amyloidozy są rodzaje białek, $z$ których powstaje amyloid [7]. Znanych jest ponad 20 białek, które mogą tworzyć amyloid. Jedna z dziedzicznych postaci amyloidozy to amyloidoza transtyretynowa (ATTR, transthyretin-related amyloidosis), określana jako ATTRm, którą wywołuje mutacja w genie transtyretyny (TTR) [7]. Amyloidoza transtyretynowa może być także nabyta (ATTRwt, wild-type ATTR). Średni czas przeżycia od rozpoznania choroby to 2-6 lat [8]. Amyloidoza transtyretynowa to głównie choroba neurologiczna, jednak spektrum narządów dotkniętych chorobą, a tym samym możliwych zaburzeń, jest bardzo zróżnicowane [1, 9, 10]. Jednak heterogenność kliniczna ATTR powoduje, że często pozostaje ona niezdiagnozowana, szczególnie gdy objawy neurologiczne są łagodnie nasilone lub nie występują [9]. Zastosowanie nowoczesnej diagnostyki $\mathrm{w}$ ostatnich latach i systematyczne badania duzych grup chorych wskazują na znaczenie częstsze występowanie sercowej amyloidozy ATTR. Sercową postać ATTR stwierdzono u $13 \%$ niewyselekcjonowanych pacjentów $z$ niewydolnością serca $\mathrm{z}$ zachowaną funkcją skurczową (HFpEF, heart failure with preserved ejection fraction), $\mathrm{u} 16 \%$ pacjentów $z$ ciężkim zwężeniem zastawki aortalnej poddawanych zabiegowi przezcewnikowej implantacji zastawki aortalnej (TAVI, transcatheter aortic valve implantation) czy u $5 \%$ pacjentów $z$ kardiomiopatią przerostową (HCM, hypertrophic cardiomyopathy) [11-13]. Dotychczasowe postępowanie u chorych na ATTR ograniczało się do stabilizacji stanu klinicznego, poprawy objawów i niespecyficznego wpływania na skurczową i rozkurczową niewydolność serca (HF, heart failure) za pomocą leków $z$ grup beta-adrenolityków czy antagonistów układu renina-angiotensyna-aldosternon (RAA). Podstawą każdej terapii były silnie działające diuretyki pętlowe. Takim postępowaniem częściowo można było poprawiać stan chorych, natomiast nie wpływało ono znacząco na „naturalny” przebieg choroby, który jest postępujący. Istnieje jednak szansa na zmianę dotychczasowego paradygmatu $\mathrm{w}$ związku $z$ toczącymi się badaniami. W ostatnich dniach sierpnia 2018 roku, podczas kongresu Europejskiego Towarzystwa Kardiologicznego (ESC, European Society of Cardiology) w Monachium, przedstawiono wyniki przełomowego badania - ATTR-ACT, w którym pacjentów z sercową postacią ATTR poddano leczeniu tafamidisem [14]. Tafamidis jest pochodną benoksazolu, który selektywnie i silnie wiąże się $z$ natywną tetrameryczną transtyretyną (TTR), co uniemożliwia jej dysocjację do monomerów (właśnie lączenie się monomerów TTR powoduje tworzenie złogów amyloidu). Przebadano 441 chorych na kardiomiopatię amyloidozową w przebiegu ATTR, którzy byli losowo przydziela$\mathrm{ni}(2: 1: 2)$ do leczenia tafamidisem w dawce $80 \mathrm{mg}$ lub $20 \mathrm{mg}$ albo podawania placebo i obserwowani przez 30 miesięcy. Autorzy stwierdzili istotne statystycznie zmniejszenie śmiertelności i pilnych hospitalizacji z powodu zaostrzeń choroby $\mathrm{w}$ grupie leczonych tafamidisem. Ponadto chorzy leczeni aktywnie cechowali się lepszą wydolnością fizyczną i poprawą jakości życia. Spodziewane szybkie wprowadzenie tafamidisu do praktyki klinicznej jest ogromną szansą dla pacjentów $z$ sercową postacią ATTR. Jeden $z$ warunków to sprawna i dokładna diagnostyka w celu wyodrębnienia chorych na kardiomiopatię amyloidozową w przebiegu ATTR z dużej rzeszy chorych na HF, HCM czy $z$ wadami zastawkowymi. Wprowadzenie nowych nieinwazyjnych metod diagnostycznych, $\mathrm{w}$ tym scyntygrafii, umożliwia szybkie badanie przesiewowe chorych. 
Tabela 1. Podstawowe cechy kliniczne chorych

Table 1. Baseline clinical features of the patients

\begin{tabular}{|c|c|c|c|c|}
\hline Oceniany parametr & Pierwszy pacjent & Druga pacjentka & Trzeci pacjent & Czwarty pacjent \\
\hline Wiek (lata) & 56 & 58 & 56 & 53 \\
\hline Płeć & M & $\mathrm{K}$ & M & M \\
\hline Klasa HF wg NYHA & II & III & III/IV & III \\
\hline Czas trwania objawów HF & Miesiąc & 15 lat & 2,5 mies. & 14 mies. \\
\hline $\begin{array}{l}\text { Cechy dekompensacji przy } \\
\text { przyjęciu do szpitala }\end{array}$ & Nie & $\begin{array}{l}\text { Ciastowate obrzęki } \\
\text { kończyn dolnych do } \\
\text { poziomu ud, wodo- } \\
\text { brzusze, zastój nad } \\
\text { polami płucnymi } \\
\text { (II klasa wg Killipa) }\end{array}$ & \begin{tabular}{|} 
Obrzęki kończyn dol- \\
nych do wysokości pa- \\
chwin, wodobrzusze, \\
bez zastoju \\
w krążeniu płucnym
\end{tabular} & Nie \\
\hline Omdlenie w wywiadzie & Nie & Nie & Nie & Omdlenie \\
\hline Wywiad rodzinny & Negatywny & Dodatni & Negatywny & Negatywny \\
\hline
\end{tabular}

M - mężczyzna; K — kobieta; HF (heart failure) — niewydolność serca; NYHA — New York Heart Association

Jako ośrodek referencyjny w odniesieniu do leczenia kardiomiopatii ośrodek autorów niniejszego opracowania ma duże doświadczenie w diagnostyce amyloidozy sercowej (dotychczas opartej na biopsji narządowej, w tym serca), a od kilku lat wykonuje się w nim scyntygrafię ATTR, co pozwala zbadać znacznie większą liczbę pacjentów. Należy podkreślić, że choć dodatni wynik scyntygrafii serca $\mathrm{u}$ chorego na amyloidozę bardzo silnie przemawia za rozpoznaniem ATTR, to jednak jest to metoda pośrednia $\mathrm{w}$ stosunku do referencyjnych technik typowania amyloidu, takich jak spektrometria mas, badanie immunohistochemiczne czy immunomikroskopia elektronowa. Ponizej przedstawiono serię opisów 4 przypadków chorych na ATTR ze zwróceniem szczególnej uwagi na proces diagnostyczny.

\section{Wyniki i dyskusja}

\section{Cechy kliniczne (tab. 1)}

Spośród analizowanych przypadków większość chorych to mężczyźni (3:1), co odpowiada występowaniu choroby w populacji ogólnej [9]. Prezentowana populacja jest młodsza w odniesieniu do średniego wieku pacjentów z ATTR, która występuje zwykle u osób powyżej 60. roku życia [8]. Ze względu na fakt, że początkowe objawy choroby zwykle są niecharakterystyczne i latwe do przeoczenia, rozpoznanie ATTR jest zazwyczaj opóźnione, a chorzy są zwykle w złym stanie klinicznym $\mathrm{w}$ momencie diagnozy (w opisanych przypadkach: w $\geq$ II klasie czynnościowej wg NYHA [New York Heart Association], ze znacznie podwyższonym stężeniem N-końcowego fragmentu propeptydu natriuretycznego typu B [NT-proBNP, $N$-terminal pro-B-type natriuretic peptide], $\mathrm{z}$ obecnymi cechami dekompensacji krążenia) [9]. U tych pacjentów czas trwania objawów HF jest bardzo zróżnicowany (tj. duszność wysiłkowa czy spoczynkowa, pogorszenie tolerancji wysiłku, cechy dekompensacji krążenia pod postacią obrzęków obwodowych czy zastoju w krążeniu płucnym), co powoduje znaczne zróżnicowanie zaprezentowanych przypadków.

Pierwszy chory został skierowany do ośrodka autorów ze szpitala rejonowego $z$ podejrzeniem HCM (maksymalna opisywana grubość mięśnia lewej komory $\leq 25 \mathrm{~mm}$ ). W trakcie diagnostyki w wyżej wspomnianym ośrodku obraz rezonansu magnetycznego sugerował możliwość spichrzeniowej postaci kardiomiopatii, co skłoniło do wykonania scyntygrafii serca ukierunkowanej na obecność ATTR, której wynik był dodatni.

Druga chora była od wielu lat leczona $z$ powodu HF na tle HCM. $Z$ powodu stopniowego pogorszenia kurczliwości lewej komory (ocenionego za pomocą frakcji wyrzutowej [EF, ejection fraction]) skierowano tę pacjentkę na poszerzoną diagnostykę w krakowskim ośrodku. W wykonanym badaniu echokardiograficznym obraz odcinkowej kurczliwości lewej komory i heterogenność mięśnia sugerowały amyloidozę, którą początkowo potwierdzono w biopsji mięśnia prawej komory, a następnie zidentyfikowano jako ATTR w scyntygrafii serca.

Trzeciego chorego przyjęto do ośrodka autorów po wstępnej diagnostyce genetycznej $z$ mutacją genu TTR. Przed hospitalizacją we wspomnianym ośrodku cechował go krótki wywiad szybko narastających objawów HF ze znacznym przerostem lewej komory i obniżoną EF. $Z$ tego 
Tabela 2. Elektrokardiograficzna podstawowa charakterystyka pacjentów

Table 2. Electrocardiographic baseline characteristics of the patients

\begin{tabular}{|c|c|c|c|c|}
\hline Oceniany parametr & Pierwszy pacjent & Druga pacjentka & Trzeci pacjent & Czwarty pacjent \\
\hline Rodzaj rytmu & Zatokowy & Zatokowy & Zatokowy & Zatokowy \\
\hline AF w wywiadzie & Brak & Napadowe & Brak & Brak \\
\hline $\mathrm{HR}[/ \mathrm{min}]$ & 75 & 70 & 75 & 85 \\
\hline QRS [ms] & 110 & 80 & $160-$ LBBB & 80 \\
\hline QTc [ms] & 380 & 450 & 400 & 460 \\
\hline $\begin{array}{l}\text { Zespoły QS/patologiczne } \\
\text { załamki Q }\end{array}$ & - & $\begin{array}{c}\text { Zespoły QS w odpro- } \\
\text { wadzeniach I, aVL, } \\
\text { V2-V3 }\end{array}$ & - & $\begin{array}{c}\text { W odprowadzeniach } \\
\text { I, aVL, V1-V4 }\end{array}$ \\
\hline Zmiany odcinka ST & $\begin{array}{c}\text { Uniesienia w odpro- } \\
\text { wadzeniach V2-V5 } \\
\text { do } 1,5 \mathrm{~mm}\end{array}$ & - & - & - \\
\hline Ujemne załamki T & $\begin{array}{c}\text { W odprowadzeniach } \\
\text { III, aVF }\end{array}$ & $\begin{array}{c}\text { W odprowadzeniach } \\
\text { III, aVF }\end{array}$ & - & $\begin{array}{c}\text { W odprowadzeniach } \\
\text { V5-V6 }\end{array}$ \\
\hline $\begin{array}{l}\text { VT w badaniu EKG metodą } \\
\text { Holtera }\end{array}$ & Nie & Nie & Nie & 1 epizod nsVT \\
\hline
\end{tabular}

AF (atrial fibrillation) - migotanie przedsionków; HR (heart rhythm) - rytm serca; VT (ventricular tachycardia) - tachykardia komorowa; LBBB (left bundle branch block) - blok lewej odnogi pęczka Hisa; nsVT (non-sustained VT) - nieutrwalona VT

powodu choremu zalecono wykonanie badania genetycznego, którego wynik był dodatni w kierunku ATTR. W celu potwierdzenia zajęcia mięśnia sercowego u pacjenta wykonano biopsję mięśnia prawej komory.

Czwarty chory trafił do ośrodka autorów ze szpitala rejonowego (do którego zgłosił się z cechami znacznej dekompensacji i niestabilności krążeniowej) w związku z podejrzeniem kardiomiopatii restrykcyjnej. W wykonanej scyntygrafii serca potwierdzono ATTR.

\section{Elektrokardiografia (tab. 2)}

Najbardziej charakterystycznym obrazem elektrokardiograficznym (EKG) u chorych na ATTR jest niski woltaż zespołów QRS ( $<5 \mathrm{~mm}$ ) ze słabą progresją załamków $\mathrm{R}$ w odprowadzeniach przedsercowych [15]. Jednakże u niektórych osób $z$ chorobą w zaawansowanym stadium występują cechy przerostu lewej komory. Inne znaleziska EKG to w około $25 \%$ przypadków - zaburzenia przewodnictwa przedsionkowo-komorowego (niewystępujące u przedstawionych chorych), a w około 15\% przypadków - śródkomorowego (blok lewej odnogi pęczka Hisa [LBBB, left bundle branch block] $\mathrm{w} 1 \mathrm{z} 4$ prezentowanych w niniejszej pracy przypadków) czy migotanie przedsionków w $20 \%$ przypadków (napadowe występuje u 2. pacjenta) [15].

\section{Badania laboratoryjne (tab. 3)}

Pomiary stężenia NT-proBNP — markera HF - oraz enzymów sercowych (markerów uszko- dzenia mięśnia sercowego: troponiny $\mathrm{T}$, frakcji sercowej kinazy kreatynowej [CK-MB, creatine kinase myocardial bound) i kinazy kreatynowej [CK, creatine kinase]) w osoczu krwi są bardzo istotne $\mathrm{w}$ amyloidozie. Umożliwiają monitorowanie nasilenia dekompensacji krążenia oraz zajęcia mięśnia sercowego przez złogi amyloidu [16]. Są również markerem rokowniczym w objawowej HF $[17,18]$.

W przypadku podejrzenia kardiomiopatii restrykcyjnej wywołanej spichrzaniem białek w mięśniu sercowym w pierwszej kolejności należy wykonać badanie ogólne lub całodobową zbiórkę moczu w celu oceny proteinurii oraz elektroforetyczny rozdział białek osocza [19]. W zaprezentowanej serii przypadków badanie ogólne moczu ani elektroforetyczny rozdział białek osocza nie ujawniły patologii. Natomiast u trzeciego pacjenta $\mathrm{w}$ wykonanych badaniach laboratoryjnych zaobserwowano nieznacznie podwyższone parametry nerkowe oraz wątrobowe, co może sugerować zajęcie również tych narządów przez białka amyloidu.

\section{Badanie echokardiograficzne (tab. 4)}

Jedną $z$ manifestacji ATTR jest postać sercowa. Jednak na początkowym etapie choroby często obraz echokardiograficzny serca pozostaje prawidłowy, a jedynie niewielkie zmiany w rezonansie magnetycznym (opóźnione wzmocnienie pokontrastowe) mogą sugerować patologię serca [20]. Na późniejszych etapach choroby obraz echokardiograficzny odpowiada kardiomiopatii restrykcyjnej [6]. Mięsień sercowy jest koncentrycznie pogrubiały 
Tabela 3. Badania laboratoryjne chorych

Table 3. Laboratory findings of the patients

\begin{tabular}{|c|c|c|c|c|}
\hline Oceniany parametr & Pierwszy pacjent & Druga pacjentka & Trzeci pacjent & Czwarty pacjent \\
\hline WBC [tys. $/ \mu \mathrm{l}]$ & 8,4 & 6,2 & 6,8 & 6,5 \\
\hline $\mathrm{RBC}[\mathrm{m} / \mathrm{n} / \mu \mathrm{l}]$ & 4,9 & 4,5 & 5,7 & 5,3 \\
\hline $\mathrm{Hb}[\mathrm{g} / \mathrm{dl}]$ & 14,9 & 11,4 & 16,1 & 15,4 \\
\hline Hct (\%) & 44,7 & 35,3 & 49,7 & 47,9 \\
\hline PLT [tys./ $/ \mu l]$ & 295 & 227 & 226 & 139 \\
\hline Kreatynina $[\mu \mathrm{mol} / \mathrm{l}]$ & 73 & 66 & 126 & 77 \\
\hline eGFR $[\mathrm{ml} / \mathrm{min}]$ & 99 & 89 & 55 & 99 \\
\hline Sód [mmol/l] & 144 & 133 & 135 & 139 \\
\hline Potas [mmol/l] & 5,1 & 4,2 & 5,1 & 3,9 \\
\hline AspAT [j./l] & 17 & 22 & 48 & 19 \\
\hline AIAT [j./I] & 12 & 12 & 41 & 12 \\
\hline Cholesterol [mmol/l] & 4,8 & 3,7 & 3,0 & 3,7 \\
\hline LDL [mmol/l] & 3,3 & 2,6 & 2,1 & 2,5 \\
\hline $\mathrm{HDL}[\mathrm{mmol} / \mathrm{l}]$ & 1,3 & 0,8 & 0,6 & 0,8 \\
\hline TG $[\mathrm{mmol} / \mathrm{l}]$ & 1,3 & 1,0 & 1,1 & 1,0 \\
\hline Glikemia na czczo [mmol/l] & 5,4 & 6,3 & 8,4 & 4,6 \\
\hline CK [j./l] & 39 & 112 & 70 & - \\
\hline CK-MB [j./l] & 13 & 11 & 17 & 22 \\
\hline Troponina wysokoczuła T [ng/ml] & 0,023 & 0,071 & 0,053 & 0,094 \\
\hline hs-CRP [mg/dl] & 3,2 & 4,4 & 22 & 5,3 \\
\hline NT-proBNP [pg/ml] & 163 & 7639 & 9177 & 10374 \\
\hline
\end{tabular}

WBC (white blood count) - liczba krwinek białych (leukocytów); RBC (red blood count) - liczba krwinek czerwonych (erytrocytów); Hb - hemoglobina;

Hct (hematocrite) - hematokryt; PLT (platelets) - płytki krwi; eGFR (estimated glomerular filtration rate) — szacunkowy współczynnik przesączania kłębuszkowego; AspAT (aspartate aminotransferase) — aminotransferaza asparaginianowa; AIAT (alanine aminotransferase) — aminotransferaza alaninowa; LDL (low-density lipoproteins)

— lipoproteiny o małej gęstości; HDL (high-density lipoproteins) - lipoproteiny o dużej gęstości; TG (triglycerides) - triglicerydy; CK (creatine kinase) - kinaza

keratynowa; CK-MB (CK-myocardial bound) - frakcja sercowa CK; hs-CRP (high-sensitive C-reactive protein) — białko C-reaktywne oznaczane metodą wysokoczułą;

NT-proBNP (N-terminal pro-B-type natriuretic peptide) - N-końcowy fragment propeptydu natriuretycznego typu B

(w zaprezentowanej serii przypadków maksymalna grubość lewej komory to $25 \mathrm{~mm}$ [norma $<11 \mathrm{~mm}])$, zmniejszając światło lewej komory (z najmniejszym wymiarem końcoworozkurczowym wśród prezentowanych chorych $-39 \mathrm{~mm}$ ) (ryc. 1). Depozycja białka TTR w mięśniu sercowym zwykle na początku choroby nie zaburza funkcji skurczowej lewej komory - wśród opisywanych pacjentów jedynie pierwsza osoba miała zachowaną funkcję skurczową lewej komory (EF 64\%) ze względu na wczesne rozpoznanie choroby. Mimo zachowanej kurczliwości globalnej lewej komory częstym obrazem występującym również już na początku choroby są odcinkowe zaburzenie kurczliwości w zakresie segmentów przypodstawnych [21]. Już od początku choroby znacznie zwiększona jest sztywność lewej komory (oceniona na podstawie stosunku fal E/A i E/E'), co powoduje rozkurczową HF. Echokardiograficzne cechy dysfunkcji rozkurczowej lewej komory są obecne u wszystkich zaprezentowanych pacjentów. Jednak najsłabiej wyrażone pozostają u pierwszego pacjenta, co sugeruje wcześniejszą postać choroby.

\section{Pozostałe badania diagnostyczne (tab. 5)}

Badaniem uzupełniającym w przypadku podejrzenia amyloidozy serca jest rezonans magnetyczny (ryc. 2). Charakterystycznym obrazem $\mathrm{w}$ rezonansie magnetycznym serca $\mathrm{w}$ kardiomiopatiach spichrzeniowych jest późne wzmocnienie pokontrastowe, w amyloidozie występujące równomiernie głównie podwsierdziowo [22]. Na podstawie takiego obrazu serca wysnuto podejrzenie amyloidozy u pierwszego pacjenta, co ostatecznie pozwoliło ustalić rozpoznanie ATTR.

Aby potwierdzić odkładanie się amyloidu w mięśniu sercowym, wykonuje się biopsję prawej komory serca. Biopsję mięśnia sercowego należy rozważyć u pacjentów $z$ przerostem mięśnia lewej komory, u których wykluczono nadciśnienie tętnicze, wady zastawkowe i rodzinną postać HCM. Następnie $\mathrm{w}$ badaniu histopatologicznym pobranego 
Tabela 4. Echokardiograficzna podstawowa charakterystyka chorych

Table 4. Echocardiographic baseline characteristics of the patients

\begin{tabular}{|l|c|c|c|c|}
\hline Oceniany parametr & Pierwszy pacjent & Druga pacjentka & Trzeci pacjent & Czwarty pacjent \\
\hline LVEDd [mm] & 44 & 39 & 40 & 43 \\
\hline LVESd [mm] & 29 & 20 & 30 & 34 \\
\hline IVS [mm] & 23 & 18 & 24 & 22 \\
\hline Maks. grubość LV [ml] & $\begin{array}{c}\text { 25. segment środkowej } \\
\text { ściany przednio- } \\
\text {-przegrodowej }\end{array}$ & 18 & 24 & 24 \\
\hline Przerost RV & Nie & Do 9 mm & Do 9 mm & Nie \\
\hline Maks. gradient w drodze & 10 & 5 & 7 & 9 \\
wypływu LV [mm Hg] & 64 & 35 & 35 & 40 \\
\hline EF (\%) & 23 & 28 & 26 & 39 \\
\hline Powierzchnia LA [cm ${ }^{2}$ ] & 17 & 27 & 17 & 29 \\
\hline Powierzchnia RA [cm ${ }^{2}$ ] & 0,74 & 3,34 & 2,72 & 2,8 \\
\hline E/A & 6 & 20,5 & 21 & 18.4 \\
\hline E/E' & tagodna & Umiarkowana & Śladowa & Umiarkowana \\
\hline Niedomykalność mitralna & 15 & 53 & 30 & 44 \\
\hline PASP [mm Hg] & Ślad & Do 12 mm & Ślad & Brak \\
\hline Płyn w worku osierdziowym & & & & \\
\hline
\end{tabular}

LVEDd (left ventricular end-diastolic diameter) - wymiar końcoworozkurczowy lewej komory; LVESd (left ventricular end-systolic diameter) - wymiar końcowoskurczowy lewej komory; IVS (intraventricular septum) - przegroda międzykomorowa; LV (left ventricle) — lewa komora; RV (right ventricle) - prawa komora; EF (ejection fraction) - frakcja wyrzutowa; LA (left atrium) - lewy przedsionek; RA (right atrium) - prawy przedsionek; PASP (systolic pulmonary artery pressure) — szacowane skurczowe ciśnienie w tętnicy płucnej

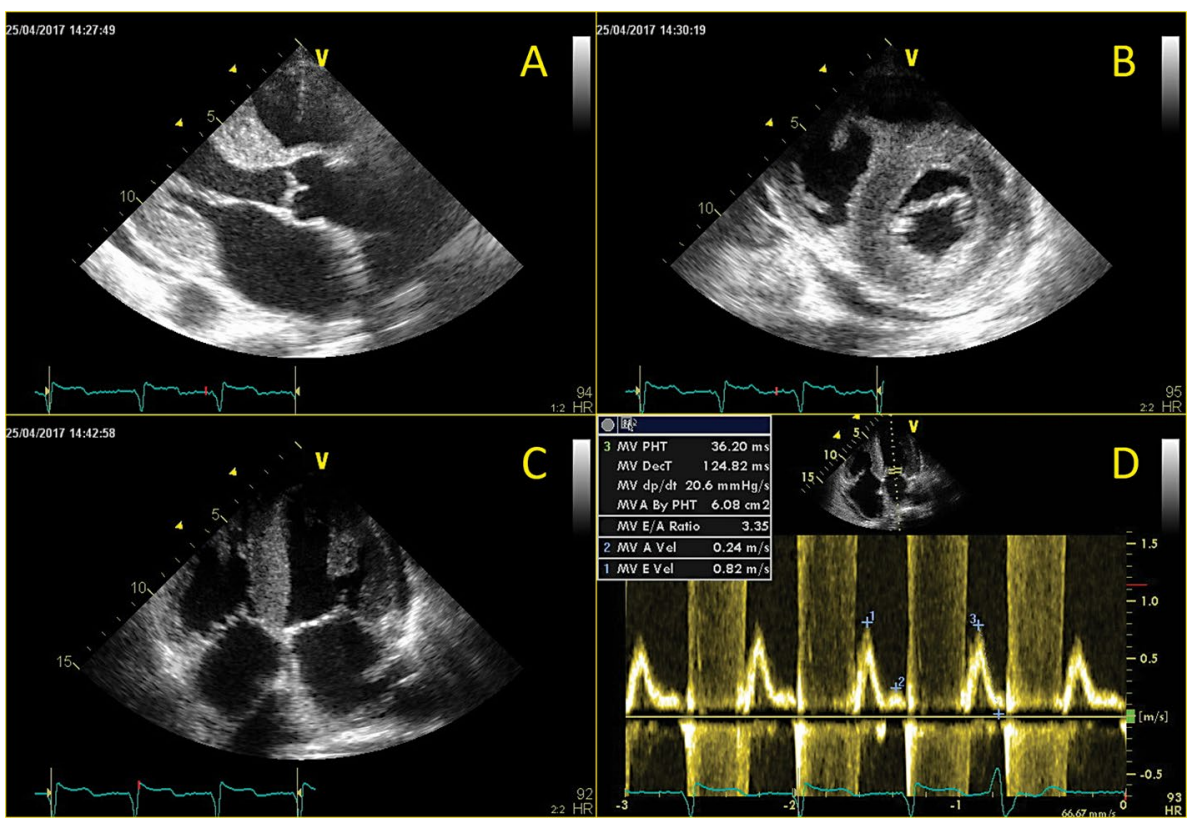

Rycina 1A-D. Badanie echokardiograficzne drugiej pacjentki: A. Projekcja przymostkowa w osi długiej — pogrubienie ścian mięśnia lewej komory głównie w zakresie przegrody międzykomorowej; B. Projekcja przymostkowa w osi krótkiej na wysokości zastawki mitralnej; C. Projekcja koniuszkowa czterojamowa. Powiększenie obu przedsionków, płyn w worku osierdziowym i koncentryczny przerost niejednorodnego mięśnia lewej komory; D. Przepływ przez zastawkę mitralną zarejestrowany metodą doplera pulsacyjnego - cechy restrykcji mięśnia lewej komory (fala E/A > 2)

Figure 1A-D. Echocardiography images of the second patient. Hypertrophy of intraventricular septum, enlargement of both atria, restrictive mitral inflow: A. Parasternal long axis view; B. Parasternal short axis view; C. Apical 4-chamber view; D. Mitral valve inflow assessed by the pulsed wave Doppler 
Tabela 5. Pozostałe badania diagnostyczne pacjentów

Table 5. Other diagnostic tests of the patients

\begin{tabular}{|l|c|c|c|c|}
\hline Oceniany parametr & \multicolumn{1}{|c|}{ Pierwszy pacjent } & Druga pacjentka & Trzeci pacjent & Czwarty pacjent \\
\hline Rezonans magnetyczny & $\begin{array}{c}\text { Ogniska późnego } \\
\text { trastowego podwsier- } \\
\text { dziowo } \\
\text { i śródściennie } \\
\text { w całym miokardium }\end{array}$ & $\begin{array}{c}\text { Nieobecne późne } \\
\text { wzmocnienie } \\
\text { pokontrastowe }\end{array}$ & - & - \\
\hline Biopsja prawej komory serca & $\begin{array}{c}\text { Złogi amyloidu } \\
\text { w podścielisku }\end{array}$ & $\begin{array}{c}\text { Przerost kardiomiocy- } \\
\text { tów, złogi amyloidu } \\
\text { w podścielisku }\end{array}$ & $\begin{array}{c}\text { Obfite złogi amyloidu } \\
\text { w podścielisku, } \\
\text { cechy przerostu } \\
\text { kardiomiocytów }\end{array}$ & - \\
\hline $\begin{array}{l}\text { Scyntygrafia serca } \\
\text { w kierunku ATTR }\end{array}$ & $\begin{array}{c}\text { Złogi amyloidu } \\
\text { w zakresie IVS }\end{array}$ & $\begin{array}{c}\text { Złogi amyloidu } \\
\text { w zakresie IVS, } \\
\text { ściany przedniej } \\
\text { i w koniuszku LV }\end{array}$ & - & $\begin{array}{c}\text { Złogi amyloidu } \\
\text { w zakresie IVS } \\
\text { i ściany przedniej }\end{array}$ \\
\hline $\begin{array}{l}\text { Badanie genetyczne } \\
\text { w kierunku ATTR }\end{array}$ & - & - & Dodatni & - \\
\hline
\end{tabular}

ATTR (transthyretin-related amyloidosis) — amyloidoza transtyretynowa; IVS (intraventricular septum) — przegroda międzykomorowa; LV (left ventricle) — lewa komora

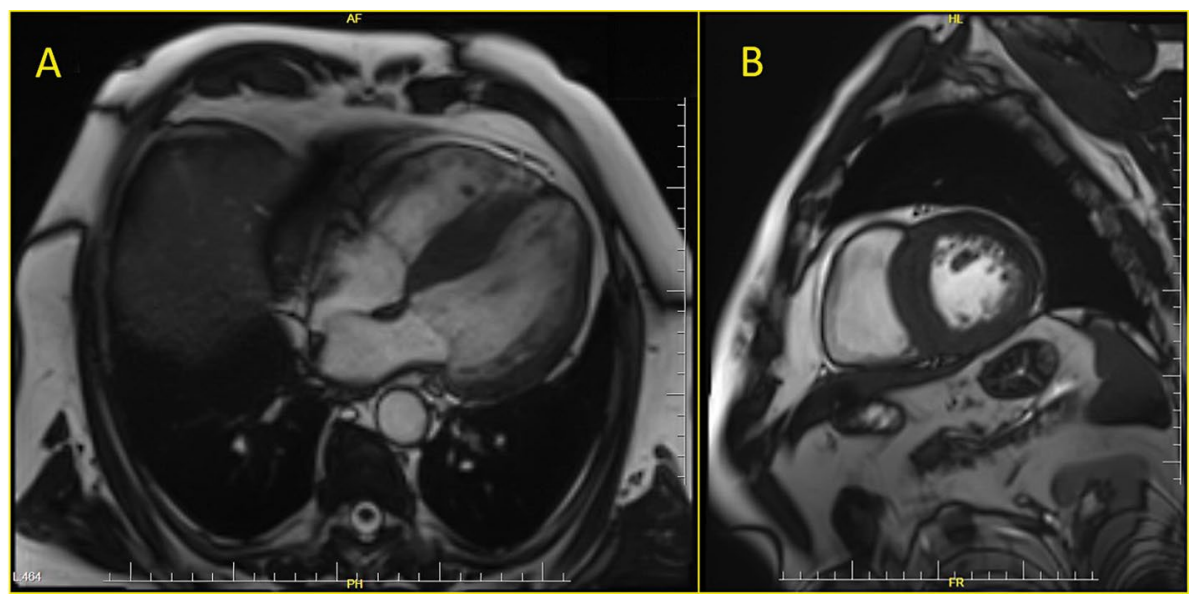

Rycina 2. Badanie rezonansu magnetycznego serca u pierwszego pacjenta: A. Projekcja czterojamowa; B. Projekcja trójjamowa. Przerost mięśnia lewej komory, najsilniej wyrażony w zakresie przegrody międzykomorowej

Figure 2. Magnetic resonance imaging of the first patient; A. 4-chamber view; B. 3-chamber view. Left ventricular hypertrophy, the strongest expressed in the interventricular septum

wycinka mięśnia sercowego ocenia się obecność białka poprzez barwienie czerwienią Kongo.

W celu diagnostyki rodzaju amyloidu odkładanego $\mathrm{w}$ miokardium wykonywane są początkowo wspomniane powyżej badania laboratoryjne w kierunku amyloidozy łańcuchów lekkich (AL, light chain amyloidosis). W przypadku ujemnych wyników badań laboratoryjnych diagnostykę można poszerzyć o scyntygrafię mięśnia sercowego w kierunku obecności amyloidu TTR lub w kierunku obecności mutacji w genie transtyretyny.

\section{Scyntygrafia serca w kierunku ATTR}

Tomografia emisyjna pojedynczego fotonu (SPECT, single-photon emission computed tomography) jest przydatna w wykrywaniu transtyretynowej amyloidozy serca. W badaniu wykorzystuje się radioizotop technetu $99 \mathrm{~m}$ oraz znaczniki klasycznie wykorzystywane w badaniu kośćca: kwas 3,3-difosfono-1,2-propanodikarboksylowy (DPD, 3,3-diphosphono-1,2-propanodicarboxylic acid), kwas metylenodifosfoniowy (MDP, methylene diphosphonic acid), pirofosforan (PYP, pyrophosphate) [23]. 
Najczęściej używanym znacznikiem w Europie jest $99 \mathrm{~m}$ Tc-DPD. Nie jest on zarejestrowany w Stanach Zjednoczonych, gdzie obecnie najbardziej rozpowszechniony jest ${ }^{99 m}$ Tc-MDP. Większość doniesien naukowych na temat zastosowania scyntygrafii kości $\mathrm{w}$ rozpoznawaniu amyloidozy serca dotyczy ${ }^{99 \mathrm{~m} T c-}$ -DPD oraz PYP [24]. Należy jednak zauważyć, że SPECT w kierunku amyloidozy serca wykonuje się głównie, opierając się na zróżnicowanych protokołach obrazowania kości, $z$ różnymi kryteriami diagnostycznymi, co może utrudniać bezpośrednie porównanie wyników dotychczas przeprowadzonych badań [25-30]. Chociaż doniesienia o roli scyntygrafii w wykrywaniu złogów amyloidu w sercu opublikowano kilkadziesiąt lat temu, to mechanizm molekularny gromadzenia się omówionych wyżej znaczników w sercu pozostaje nieznany [31].

Wykorzystanie tej nieinwazyjnej metody w różnicowaniu zajęcia serca w przebiegu AL oraz ATTR zwalidowano w jednoośrodkowym badaniu przeprowadzonym przez Perugini i wsp. [26]. Autorzy wprowadzili ponadto wykorzystywaną do tej pory 4-stopniową skalę opartą na ocenie wychwytu znacznika w zakresie kości, serca i tkanek miękkich. W późniejszych wieloośrodkowych badaniach przeprowadzonych w większych grupach pacjentów wykazano korzystny profil diagnostyczny scyntygrafii w rozpoznawaniu sercowej amyloidozy ATTR charakteryzujący się czułością przekraczającą $90 \%$ [31, 32]. W badaniu, do którego włączono 1217 pacjentów, uwzględniającym zarówno SPECT $z$ 99mTc-PYP, jak i 99m Tc-DPD, negatywny wynik wykluczał ATTR w 99\%. Specyficzność pozytywnego obrazu wynosiła $86 \%$, co było związane $z$ występowaniem niewielkiego wychwytu znacznika u pacjentów $z$ amyloidozą AL. Zaproponowano połączenie pozytywnego wyniku scyntygrafii kości $z$ brakiem obecności białka monoklonalnego we krwi lub moczu, co wiązało się ze wzrostem specyficzności do $100 \%$ [10]. W niedawno przeprowadzonym w ośrodkach amerykańskich badaniu dowiedziono, że SPECT $z$ użyciem PYP cechuje się 88-procentową czułością i specyficznością $\mathrm{w}$ wykrywaniu zajęcia serca w przebiegu ATTR. Po wprowadzeniu współczynnika serce-przeciwległe płuco, przy punkcie odcięcia ponad 1,6, czułość wynosiła $91 \%$, a swoistość $92 \%$ [32].

Udowodniono ponadto, że wychwyt znacznika w SPECT kości koreluje $z$ przerostem mięśnia lewej komory obserwowanym w badaniu echokardiograficznym. Zmiany scyntygraficzne można jednak zaobserwować na wcześniejszym etapie choroby, kiedy grubość mięśnia nie przekracza punktu odcięcia $12 \mathrm{~mm}$ [33]. W badaniach obser- wacyjnych uwzględniających 12521 pacjentów, u których wykonano SPECT kości, częstość występowania amyloidozy serca oceniono na $0,36 \%$ [34]. $\mathrm{W}$ nowszych doniesieniach $z$ wykorzystaniem tej metody podkreśla się jednak możliwość częstszego występowania choroby w szczególnych populacjach pacjentów - u $13 \%$ osób z HFpEF, w $5 \%$ przypadków HCM oraz u 16\% pacjentów z ciężką stenozą aortalną [11-13],

W Zakładzie Medycyny Nuklearnej Krakowskiego Szpitala im. Jana Pawła II wykonywane są badania scyntygrafii kości z użyciem DPD w celu oceny amyloidozy serca. Na rycinie 3 ukazano przykładowy wynik badania $z$ zajęciem serca $\mathrm{w}$ przebiegu postaci ATTR.

\section{Leczenie}

Podstawowymi lekami stosowanymi w amyloidozie serca ATTR są leki podawane w HF zwłaszcza inhibitory enzymu konwertującego angiotensynę, inhibitory receptora dla angiotensyny II, antagoniści receptora mineralokortykoidowego (tab. 6). Istnieją kontrowersje dotyczące szerokiego stosowania beta-adrenolityków. $Z$ jednej strony, przez spowolnienie częstości pracy serca mogą one osłabiać rezerwę chronotropową i w konsekwencji zmniejszać pojemność minutową, zwłaszcza przy wysiłku, ale $z$ drugiej strony nieco poprawiają upośledzoną funkcję rozkurczową i umożliwiają uzyskanie kontroli nad szybkimi arytmiami nadi komorowymi, zwłaszcza migotaniem przedsionków, które są bardzo częste w kardiomiopatii restrykcyjnej i amloidozie sercowej. Ostrożna terapia beta-adrenolitykami w ośrodkach referencyjnych o dużym doświadczeniu jest stosowana $z$ racji braku alternatyw (digoksyna, podobnie jak i niedihdropirydynowi antagoniści wapnia, jest jednoznacznie przeciwwskazana) [17].

Trwają badania nad celowanymi lekami w amyloidozie ATTR, w tym u pacjentów $z$ zajęciem serca. Jest badany lek tafamidis stabilizujący białko TTR. Tafamidis łączy się do TTR, uniemożliwiając jej rozpad na monomery, co znacznie spowalnia tworzenie amyloidu, a tym samym postęp choroby [35]. Niedawno opublikowane, przeprowadzone metodą podwójnie ślepej próby randomizowane badanie eksperymentalne, obejmujące 441 pacjentów, ukazuje zmniejszenie śmiertelności (30\% v. 43\%) i częstości hospitalizacji sercowo-naczyniowych $(0,48 /$ rok $v$. 0,70/rok) u pacjentów leczonych przez 30 miesięcy tafamidisem w dawce $20 \mathrm{mg}$ lub $80 \mathrm{mg}$ w stosunku do podawania placebo [14]. Co więcej, chorzy leczeni tafamidisem charakteryzowali się 


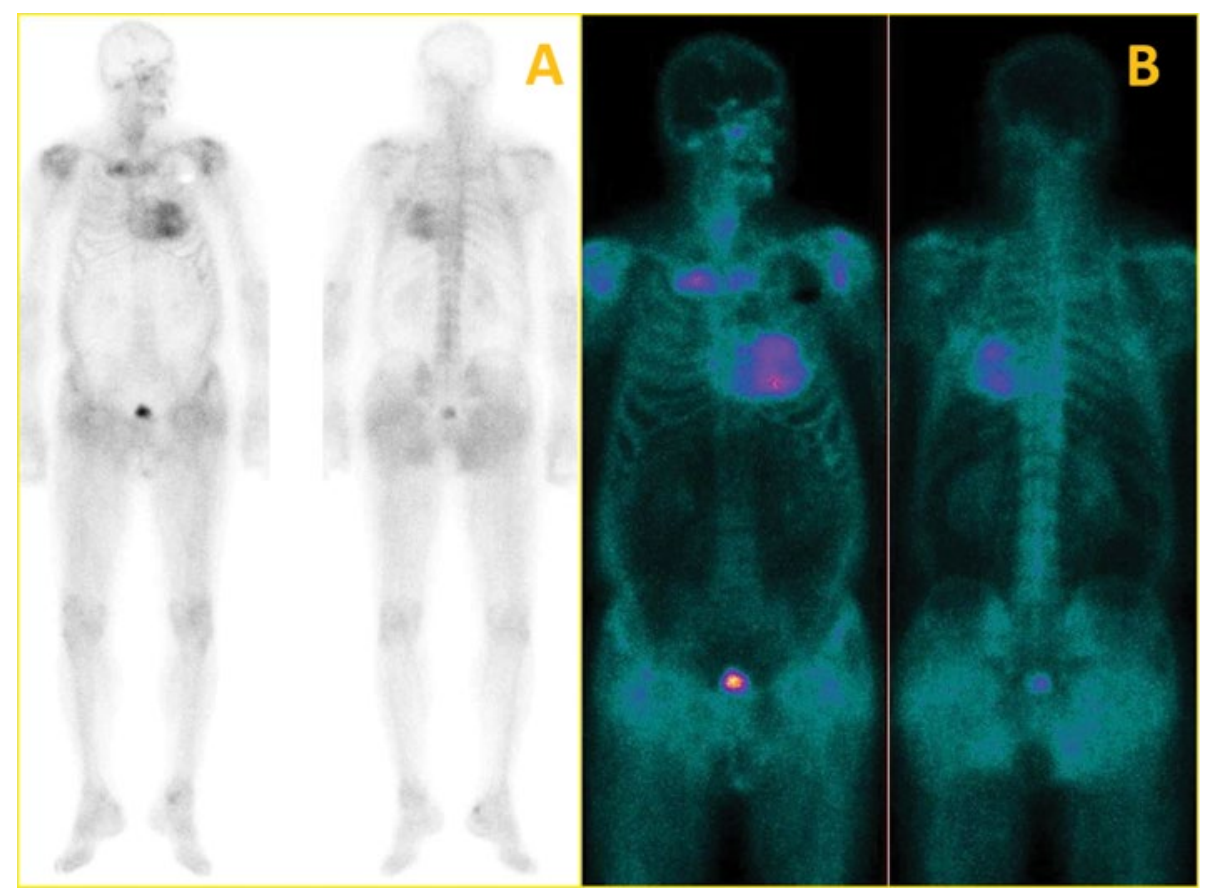

Rycina 3A-B. Badanie scyntygraficzne po podaniu preparatu 99mTc-DPD w skanach planarnych (A) oraz w badaniu tomografii emisyjnej pojedynczego fotonu (B). Uwidoczniono znaczne wzmożone gromadzenie znacznika w rzucie serca (A), głównie w zakresie przegrody międzykomorowej, a także ściany dolnej lewej komory serca (B). Wynik pozytywny dla zajęcia serca w przebiegu amyloidozy transtyretynowej (ATTR)

Figure 3A-B. ${ }^{99 m}$ Tc-DPD heart scintigraphy in the plannar imaging (A) and in the single-photon emission computed tomography (B). Positive test for transthyretin-related amyloidosis (ATTR)

Tabela 6. Leczenie pacjentów

Table 6. Treatment of the patients

\begin{tabular}{|l|c|c|c|c|}
\hline Oceniany parametr & Pierwszy pacjent & Drugz pacjentka & Trzeci pacjent & Czwarty pacjent \\
\hline Inhibitor ACE/ARB & Perindopril & - & Zofenopril & Ramipril \\
\hline Antagonista wapnia & Nebiwolol & Bisoprolol & Metoprolol & Nebiwolol \\
\hline MRA & - & Spironolakton & Eplerenon & Eplerenon \\
\hline Diuretyki & - & Furosemid $120 \mathrm{mg} / \mathrm{d}$. & Furosemid $80 \mathrm{mg} / \mathrm{d}$. & Furosemid $80 \mathrm{mg} / \mathrm{d}$. \\
\hline & & Torasemid $10 \mathrm{mg} / \mathrm{d}$. & Torasemid $120 \mathrm{mg} / \mathrm{d}$. & Torasemid $10 \mathrm{mg} / \mathrm{d}$. \\
\hline Inne leki & Lerkanidipina & Dabigatran & Lewotyroksyna & - \\
\hline
\end{tabular}

ACE (angiotensin-converting enzyme) - enzym konwertujący angiotensynę; ARB (angiotensin II receptor blockers) — inhibitory receptora dla angiotensyny II; MRA (mineralocorticoid receptor antagonists) — antagoniści receptora mineralokortykoidowego

lepszą wydolnością fizyczną ocenioną za pomocą testu 6-minutowego marszu.

\section{Wnioski}

Amyloidoza transtyretynowa jest chorobą ciągle sprawiającą problemy diagnostyczne $z$ powodu znacznej heterogenności obrazu klinicznego obejmującego szerokie spektrum — od objawów jedynie neurologicznych, po prezentacje bez zajęcia układu nerwowego. Ta różnorodność wiąże się ze specyficznymi mutacjami genu transtyretyny, często występującymi jedynie endemicznie. Coraz częściej rozpoznaje się również postać nabytą ATTR (ATTRwt), w której dochodzi do odkładania prawidłowego białka, przede wszystkim w sercu w populacji mężczyzn w starszym wieku. Możliwość zajęcia jedynie serca w przebiegu ATTR powoduje, 
że u każdego pacjenta $z$ przerostem miokardium lewej komory powinno się brać pod uwagę występowanie fenokopii HCM w przebiegu amyloidozy, szczególnie biorąc pod uwagę obiecujące wyniki ostatnich badań klinicznych $z$ zastosowaniem tafamidisu.

\section{Konflikt interesów}

Autorzy oświadczają, że nie mają powiązań ani finansowych zależności z żadną organizacją lub kimkolwiek posiadającym bezpośredni wkład w przedmiot badań.

\section{Piśmiennictwo}

1. Shah KB, Inoue Y, Mehra MR. Amyloidosis and the heart: a comprehensive review. Arch Intern Med. 2006; 166(17): 1805-1813, doi: 10.1001/archinte.166.17.1805, indexed in Pubmed: 17000935 .

2. Gilead S, Gazit E. Inhibition of amyloid fibril formation by peptide analogues modified with alpha-aminoisobutyric acid. Angew Chem Int Ed Engl. 2004; 43(31): 4041-4044, doi: 10.1002/ /anie.200353565, indexed in Pubmed: 15300690.

3. Kagan BL, Azimov R, Azimova R. Amyloid peptide channels. J Membr Biol. 2004; 202(1): 1-10, doi: 10.1007/s00232-004-0709-4, indexed in Pubmed: 15702375.

4. Kadowaki $\mathrm{H}$, Nishitoh $\mathrm{H}$, Urano F, et al. Amyloid beta induces neuronal cell death through ROS-mediated ASK1 activation. Cell Death Differ. 2005; 12(1): 19-24, doi: 10.1038/sj.cdd.4401528, indexed in Pubmed: 15592360.

5. Maron BJ, Towbin JA, Thiene G, et al. Contemporary definitions and classification of the cardiomyopathies: an American Heart Association Scientific Statement from the Council on Clinical Cardiology, Heart Failure and Transplantation Committee; Quality of Care and Outcomes Research and Functional Genomics and Translational Biology Interdisciplinary Working Groups; and Council on Epidemiology and Prevention. Circulation. 2006; 11(113): 1807-1816, doi: 10.1161/CIRCULATIONAHA.106.174287, indexed in Pubmed: 16567565.

6. Elliott P, Andersson B, Arbustini E, et al. Classification of the cardiomyopathies: a position statement from the European Society Of Cardiology Working Group on Myocardial and Pericardial Diseases. Eur Heart J. 2008; 29(2): 270-276, doi: 10.1093/eurheartj/ /ehm342, indexed in Pubmed: 17916581.

7. Westermark P, Benson MD, Buxbaum JN, et al. A primer of amyloid nomenclature. Amyloid. 2007; 14(3): 179-183, doi: 10.1080/13506120701460923, indexed in Pubmed: 17701465.

8. Ruberg FL, Berk JL. Transthyretin (TTR) cardiac amyloidosis. Circulation. 2012; 126(10): 1286-1300, doi: 10.1161/CIRCULATIONAHA.111.078915, indexed in Pubmed: 22949539.

9. Planté-Bordeneuve V, Ferreira A, Lalu T, et al. Diagnostic pitfalls in sporadic transthyretin familial amyloid polyneuropathy (TTR-FAP). Neurology. 2007; 69(7): 693-698, doi: 10.1212/01. wnl.0000267338.45673.f4, indexed in Pubmed: 17698792.

10. Rapezzi C, Quarta CC, Riva L, et al. Transthyretin-related amyloidoses and the heart: a clinical overview. Nat Rev Cardiol. 2010; 7(7): 398-408, doi: 10.1038/nrcardio.2010.67, indexed in Pubmed: 20479782 .
11. Damy T, Costes B, Hagège AA, et al. Prevalence and clinical phenotype of hereditary transthyretin amyloid cardiomyopathy in patients with increased left ventricular wall thickness. Eur Heart J. 2016; 37(23): 1826-1834, doi: 10.1093/eurheartj/ehv583, indexed in Pubmed: 26537620.

12. González-López E, Gallego-Delgado M, Guzzo-Merello G, et al. Wild-type transthyretin amyloidosis as a cause of heart failure with preserved ejection fraction. Eur Heart J. 2015; 36(38): 2585-2594, doi: 10.1093/eurheartj/ehv338, indexed in Pubmed: 26224076.

13. Castaño A, Narotsky DL, Hamid N, et al. Unveiling transthyretin cardiac amyloidosis and its predictors among elderly patients with severe aortic stenosis undergoing transcatheter aortic valve replacement. Eur Heart J. 2017; 38(38): 2879-2887, doi: 10.1093/ /eurheartj/ehx350, indexed in Pubmed: 29019612.

14. Maurer MS, Schwartz JH, Gundapaneni B, et al. ATTR-ACT Study Investigators. Tafamidis treatment for patients with transthyretin amyloid cardiomyopathy. N Engl J Med. 2018; 379(11): 1007-1016, doi: 10.1056/NEJMoa1805689, indexed in Pubmed: 30145929.

15. Murtagh B, Hammill SC, Gertz MA, et al. Electrocardiographic findings in primary systemic amyloidosis and biopsy-proven cardiac involvement. Am J Cardiol. 2005; 95(4): 535-537, doi: 10.1016/j.amjcard.2004.10.028, indexed in Pubmed: 15695149.

16. Takemura G, Takatsu Y, Doyama K, et al. Expression of atrial and brain natriuretic peptides and their genes in hearts of patients with cardiac amyloidosis. J Am Coll Cardiol. 1998; 31(4): 754-765, indexed in Pubmed: 9525543.

17. Ponikowski P, Voors A, Anker S, et al. 2016 ESC Guidelines for the diagnosis and treatment of acute and chronic heart failure. Eur J Heart Fail. 2016; 18(8): 891-975, doi: 10.1002/ejhf.592, indexed in Pubmed: 27207191.

18. Dispenzieri A, Gertz MA, Kyle RA, et al. Prognostication of survival using cardiac troponins and $\mathrm{N}$-terminal pro-brain natriuretic peptide in patients with primary systemic amyloidosis undergoing peripheral blood stem cell transplantation. Blood. 2004; 104(6): 1881-1887, doi: 10.1182/blood-2004-01-0390, indexed in Pubmed: 15044258.

19. Desport E, Bridoux F, Sirac C, et al. Centre national de référence pour l'amylose $\mathrm{AL}$ et les autres maladies par dépôts d'immunoglobulines monoclonales. Al amyloidosis. Orphanet J Rare Dis. 2012; 7: 54, doi: 10.1186/1750-1172-7-54, indexed in Pubmed: 22909024.

20. Kristen AV, Perz JB, Schonland SO, et al. Rapid progression of left ventricular wall thickness predicts mortality in cardiac light-chain amyloidosis. J Heart Lung Transplant. 2007; 26(12): 1313-1319, doi: 10.1016/j.healun.2007.09.014, indexed in Pubmed: 18096484.

21. Park SJ, Miyazaki C, Bruce CJ, et al. Left ventricular torsion by two-dimensional speckle tracking echocardiography in patients with diastolic dysfunction and normal ejection fraction. J Am Soc Echocardiogr. 2008; 21(10): 1129-1137, doi: 10.1016/j. echo.2008.04.002, indexed in Pubmed: 18486443.

22. Maceira AM, Joshi J, Prasad SK, et al. Cardiovascular magnetic resonance in cardiac amyloidosis. Circulation. 2005; 111(2): 186-193, doi: 10.1161/01.CIR.0000152819.97857.9D, indexed in Pubmed: 15630027.

23. Chen W, Ton VK, Dilsizian V. Clinical phenotyping of transthyretin cardiac amyloidosis with bone-seeking radiotracers in heart failure with preserved ejection fraction. Curr Cardiol Rep. 2018; 20(4): 23, doi: 10.1007/s11886-018-0970-2, indexed in Pubmed: 29520480 . 
24. Algalarrondo V, Piekarski E, Eliahou L, et al. Can nuclear imaging techniques predict patient outcome and guide medical management in hereditary transthyretin cardiac amyloidosis? Curr Cardiol Rep. 2018; 20(5): 33, doi: 10.1007/s11886-018-0976-9, indexed in Pubmed: 29574587.

25. Harb SC, Haq M, Flood K, et al. National patterns in imaging utilization for diagnosis of cardiac amyloidosis: a focus on Tc99m-pyrophosphate scintigraphy. J Nucl Cardiol. 2017; 24(3): 1094-1097, doi: 10.1007/s12350-016-0478-3, indexed in Pubmed: 27016106.

26. Perugini E, Guidalotti PL, Salvi F, et al. Noninvasive etiologic diagnosis of cardiac amyloidosis using 99mTc-3,3-diphosphono-1,2-propanodicarboxylic acid scintigraphy. J Am Coll Cardiol. 2005; 46(6): 1076-1084, doi: 10.1016/j.jacc.2005.05.073, indexed in Pubmed: 16168294.

27. Kristen AV, Scherer K, Buss S, et al. Noninvasive risk stratification of patients with transthyretin amyloidosis. JACC Cardiovasc Imaging. 2014; 7(5): 502-510, doi: 10.1016/j.jcmg.2014.03.002, indexed in Pubmed: 24726252.

28. Bokhari S, Castaño A, Pozniakoff T, et al. (99m)Tc-pyrophosphate scintigraphy for differentiating light-chain cardiac amyloidosis from the transthyretin-related familial and senile cardiac amyloidoses. Circ Cardiovasc Imaging. 2013; 6(2): 195-201, doi: 10.1161/ /CIRCIMAGING.112.000132, indexed in Pubmed: 23400849.

29. Corbett JR, Lewis SE, Wolfe CL, et al. Measurement of myocardial infarct size by technetium pyrophosphate single-photon tomography. Am J Cardiol. 1984; 54(10): 1231-1236, indexed in Pubmed: 6095634.
30. Rude RE, Parkey RW, Bonte FJ, et al. Clinical implications of the technetium-99m stannous pyrophosphate myocardial scintigraphic ,doughnut” pattern in patients with acute myocardial infarcts. Circulation. 1979; 59(4): 721-730, indexed in Pubmed: 421311.

31. Gillmore JD, Maurer MS, Falk RH, et al. Nonbiopsy diagnosis of cardiac transthyretin amyloidosis. Circulation. 2016; 133(24): 2404-2412, doi: 10.1161/CIRCULATIONAHA.116.021612, indexed in Pubmed: 27143678.

32. Castano A, Haq M, Narotsky DL, et al. Multicenter study of planar technetium 99m pyrophosphate cardiac imaging: predicting survival for patients with ATTR cardiac amyloidosis. JAMA Cardiol. 2016; 1(8): 880-889, doi: 10.1001/jamacardio.2016.2839, indexed in Pubmed: 27557400.

33. Rapezzi C, Quarta CC, Guidalotti PL, et al. Role of (99m)Tc-DPD scintigraphy in diagnosis and prognosis of hereditary transthyretin-related cardiac amyloidosis. JACC Cardiovasc Imaging. 2011; 4(6): 659-670, doi: 10.1016/j.jcmg.2011.03.016, indexed in Pubmed: 21679902.

34. Longhi S, Guidalotti PL, Quarta CC, et al. Identification of TTR-related subclinical amyloidosis with $99 \mathrm{mTc}$-DPD scintigraphy. JACC Cardiovasc Imaging. 2014; 7(5): 531-532, doi: 10.1016/j. jcmg.2014.03.004, indexed in Pubmed: 24831216.

35. Quarta CC, Solomon SD. Stabilizing transthyretin to treat ATTR cardiomyopathy. N Engl J Med. 2018; 379(11): 1083 -1084, doi: 10.1056/NEJMe1810074, indexed in Pubmed: 30145933. 